\title{
Effects of Hydrological Connectivity on Snail Assemblages in the Intertidal Zone of Coastal Wetlands
}

\author{
Haitao $\mathrm{Wu}^{1}$ (D) $\cdot$ Qiang Guan ${ }^{1,2} \cdot$ Kangle $\mathrm{Lu}^{1,2} \cdot$ Guangxuan $\mathrm{Han}^{3} \cdot$ Baoquan $\mathrm{Li}^{3} \cdot$ Mengyao Yang ${ }^{1}$
}

Received: 26 April 2019 / Accepted: 22 October 2019 / Published online: 16 November 2019

(C) Society of Wetland Scientists 2019

\begin{abstract}
Hydrological connectivity controls the patterns of invertebrate assemblages in wetland ecosystems. With degradation of intertidal wetlands, artificial freshwater release has become an important restoration technique. Hydrological connectivity with tidal creeks is also a key ecological process for intertidal wetlands. However, how hydrologic connectivity affects snail assemblages remains poorly investigated in intertidal wetlands. We studied the differences in snail assemblages in wetlands to understand the effects of hydrological connectivity, wetland to river, and wetland to ocean. We found freshwater connectivity can transform intertidal snail assemblages into freshwater snail assemblages; restored wetlands primarily had freshwater snail species and natural intertidal wetlands mainly supported marine or salt-adapted snail species. Cluster analysis, nMDS plot and ANOSIM analysis showed snail assemblages were influenced strongly by hydrological connectivity. Stenothyra glabra, Oncomelania sp. and Nassarius festivus were indicators of natural intertidal wetlands. Hippeutis cantori, Radix swinhoei and Succinea pfeifferi were indicators of restored wetlands. Our results suggest natural hydrological connectivity with the ocean needs to be maintained when attempting to restore intertidal wetlands. Without this connection, connecting impaired wetlands only to rivers, may not achieve restoration of natural biotic assemblages.
\end{abstract}

Keywords Aquatic invertebrates $\cdot$ Community similarity $\cdot$ Indicator species $\cdot$ Wetland management

\section{Introduction}

Ecological studies on hydrological connectivity routinely seek to understand the connections between bodies of water and the factors that influence those connections (Fullerton et al. 2010).

\section{Highlights of this study}

-Natural hydrological connectivity with the ocean needs to be maintained when attempting to restore intertidal wetlands.

- Freshwater release may not achieve restoration of natural biotic assemblages. -Snail assemblages may serve as a robust and rapid metric to assess hydrology connectivity of coastal wetlands.

Haitao Wu

wuhaitao@neigae.ac.cn

Qiang Guan

guanqiang@neigae.ac.cn

Kangle Lu

kanglelu@neigae.ac.cn

Guangxuan Han

gxhan@yic.ac.cn

Baoquan Li

bqli@yic.ac.cn
In freshwater ecosystems, hydrological connectivity is known to influence biogeochemical fluxes (Hosen et al. 2018; Thom et al. 2018), food-web structure (Reid et al. 2012), macroinvertebrate assemblages (Reese and Batzer 2007; Leigh and Sheldon 2009; Paillex et al. 2009; Guan et al. 2017),
Mengyao Yang

yangmengyao@neigae.ac.cn

1 Key Laboratory of Wetland Ecology and Environment, Northeast Institute of Geography and Agroecology, Chinese Academy of Sciences, 4888 Shengbei Street, Changchun, Jilin, China

2 University of Chinese Academy of Sciences, Beijing 100049, China

3 Yantai Institute of Coastal Zone Research, Chinese Academy of Sciences, Yantai 264003, China 
macrophytes (Amoros and Bornette 2002), fish assemblages (Aarts et al. 2004; Lasne et al. 2007; Fullerton et al. 2010), and the zooplankton community (de Paggi and Paggi 2008). Studies from rivers and bodies of water along the alluvial floodplain found that hydrological connectivity strongly influences the macroinvertebrate assemblage composition and diversity (Reese and Batzer 2007; Leigh and Sheldon 2009; Paillex et al. 2009; Guan et al. 2017). However, the influence of hydrological connectivity on invertebrates has been rarely studied in coastal wetlands. Understanding the responses of invertebrates to natural and human-induced disturbances in coastal wetlands is essential for effective coastal wetland management.

Snails (Mollusca: Gastropoda) are found in nearly all types of wetlands, including saline and freshwater habitats, and temporary and permanent habitats (Pennak 1989; Strong et al. 2008). In coastal wetlands, snail assemblages primarily consist of marine species and salt-tolerant species. The snail assemblage in ecosystems depend on snail feeding behaviors, dispersal abilities, respiratory strategies, reproductive strategies (Reckendorfer et al. 2006) and habitat modification (van der Heide et al. 2014), and these attributes make snails particularly useful for delineating impacts of environmental factors on wetlands (Wu et al. 2017, 2019; Guan et al. 2017, 2018). The diversity in taxonomy and relatively slow rates of passive dispersal may make snails potentially useful indicators for delineating effects of various environmental factors in wetlands (Wu et al. 2019). A further understanding of how environmental conditions impact the assemblage of snail species in intertidal wetlands will be important for biodiversity conservation.

Intertidal wetlands are vital for the delivery of ecosystem services through their hydrological, biogeochemical and ecological processes (Wu et al. 2018). Intertidal wetlands can degrade due to natural processes, such as sea level rise and vertical accretion, as well as human activities (Valdemoro et al. 2007; Wu et al. 2018). It is argued that restoring wetland connectivity is a valuable tool for addressing biodiversity losses in coastal environments (Thayer and Kentula 2005). For over 20 years, the Yellow River Conservancy Commission has released freshwater from the Yellow River to help restore the degraded wetlands in the Yellow River Delta (Yang et al. 2017a). The project successfully increased the water-surface area and the number of bird species and individuals, improved the vegetative landscape, and decreased the depth to the water table (Yang et al. 2017a). Due to this project, artificial freshwater release has become an important way of restoring hydrological connectivity between rivers and restored areas of intertidal wetlands.

Most intertidal wetlands contain numerous tidal creeks (Mallin 2004; Wang et al. 2009), which are the primary hydrologic connection among intertidal habitats. Tidal creeks play important roles in the transfer of material and other ecological processes due to their prevalence and creation of expansive ecotonal edges (Dame et al. 2000). Tidal creeks determine the distribution of tidal flooding through complex dendritic networks (Sanderson et al. 2000), and create heterogeneous habitats for various organisms (Desmond et al. 2000; Jin et al. 2007; Wang et al. 2009). The rhythmic movements of tides are responsible for the lateral exchange of invertebrates between the intertidal and offshore zones (Ning et al. 2019), and longitudinally between upper creek and subtidal channels. The important roles of tidal creeks in determining survival and growth of invertebrates in salt marshes have been extensively investigated, and tidal creeks are now recognized as important ecotones (Mallin 2004; Wang et al. 2009).

Given the growing interest in hydrological connectivity and its potential importance for restoring intertidal wetlands, we assessed whether hydrological connectivity influences assemblages of estuarine snail species. We compared the restored wetlands versus natural intertidal wetlands to evaluate the influence of freshwater connectivity. In natural intertidal wetlands, we compared tidal creeks versus non-creek intertidal wetlands to evaluate natural tidal connectivity. First, we quantified freshwater connectivity by characterizing the species of snails in the study sites to address whether snail assemblages were different between restored wetlands and natural intertidal wetlands in Northeastern China's Yellow River Delta. Next, we quantified species of snails in the tidal creeks and non-creek intertidal wetlands of natural intertidal wetlands to detect whether the natural hydrological connectivity affected snail assemblages. Finally, we investigated whether snail taxa (genera and species) can serve as useful biological indicators for environmental variation for the Yellow River Delta.

\section{Methods and Materials}

\section{Study Area}

We assessed 33 wetlands between $37^{\circ} 36^{\prime} 17^{\prime \prime} \mathrm{N}$ and $37^{\circ} 49^{\prime}$ 9.7'N in the Yellow River Delta Nature Reserve, Shandong Province, China. The Dawenliu and Huanghekou management stations in the Yellow River Delta National Nature Reserve were included, both of which have been restored by reconnecting freshwater inputs from the Yellow River under a program approved by the Yellow River Conservancy Commission in 2002. Results of restoration of 10,000 ha of wetlands located in these areas have been previously published (Cui et al. 2009; Yang 2011). We divided the study region into two categories based on their relative freshwater connectivity: 1) restored wetlands, which received freshwater from the Yellow River, but no longer received daily tidal inputs; and 2) natural intertidal wetlands, which were located nearby in the intertidal basin and were influenced by tides, but received no restored freshwater inputs. The natural intertidal 
wetlands were further categorized into two types, tidal creeks and non-creek wetland of the intertidal zone.

The study region has a warm temperate moist monsoon climate with a mean annual temperature of 11.7 to $12.6{ }^{\circ} \mathrm{C}$ and a mean annual precipitation of 530 to $630 \mathrm{~mm}$ (Liu et al. $2018 \mathrm{a}, \mathrm{b}$ ). About $70 \%$ of the annual precipitation is rainfall during the summer months (May-July), and the annual average of the ratio of evaporation to precipitation is 3.22 . The natural vegetation of the area is salt-tolerant herbaceous plants and shrubs, especially coastal saline or salt-tolerant meadow vegetation (Yang et al. 2017b). Dominant species include Suaeda glauca (Bunge) Bunge., Suaeda salsa (L.) Pall., Tamarix chinensis Lour., Phragmites australis Trin and Spartina alterniflora Loisel (Ma et al. 2015).

\section{Field Sampling and Laboratory Processing}

The restored wetland experiences an annual release of freshwater in late June or early July. Therefore, snails (Mollusca: Gastropoda) were collected before and after releases in May and August of 2018 from 19 freshwater release wetland sites, from seven tidal creeks sites, and from seven non-creek intertidal wetland sites. Snails were sampled using a D-shaped sweep net of 35-cm diameter made of 1-mm mesh. Sweep nets sample a rich array of snails and are commonly used to collect invertebrate communities from flooded habitat (Batzer et al. 2001). Four 1-m-long horizontal sweeps were collected, scraping plant and benthic substrates at randomly selected locations in each wetland, including the different water depths, vegetation types and micro-geomorphologic conditions that were present. Because the nets sieved the water column, scraped the bottom of wetlands, and swept submersed and emergent plants the complete range of snails available at each site were collected (Batzer et al. 2001; Meyer et al. 2013). The four $0.35 \mathrm{~m} \times 1 \mathrm{~m}$ sub-samples per wetland per date were pooled and stored in labeled plastic bags, and then preserved in $95 \%$ ethanol. In the laboratory, snails were hand sorted from sediment and plant debris under a dissecting microscope, and then re-preserved in 95\% ethanol. Snails were identified to the lowest taxonomic level practical using standard references, keys, and guides (Liu et al. 1979; Qi et al. 1985; Wang and Song 2017; Leng et al. 2017). Hydrobiidae, Ariophantidae, Siliquariidae and Pupillidae were identified to the genus-level; other families were identified to the specieslevel.

\section{Statistical Analyses}

Variation in snail assemblage compositions among the study sites was assessed using taxon abundance and composition. Analysis of variance (ANOVA) was used to assess whether the abundance and species richness of snails varied between the different types of wetlands.
For the analysis of freshwater connectivity, restored wetlands were compared to natural intertidal wetlands (including both tidal creeks and non-creek intertidal wetlands); to investigate the effects of oceanic tide flows (natural hydrological connectivity), tidal creeks were compared to non-creek intertidal wetlands. We calculated snail assemblage similarities among wetlands, based on the original snail abundance data (square-root transformed), using the Bray-Curtis dissimilarity coefficient. On a triangular matrix, we conducted a Similarity Profile test (SIMPROF) to assess if significant structure existed overall among the 33 wetlands (999 permutations). As the test was significant $(\mathrm{Pi}=3.6, p=0.001)$, we were justified in further exploring how sites or taxa grouped. Cluster analyses and non-metric multi-dimensional scaling ordination (nMDS) were used to visualize snail species composition in different sites and identify patterns in species composition across different wetland types. Analysis of similarity (ANOSIM) was used to assess differences between groups of assemblage samples, with 999 permutations on each resemblance matrix. Indicator species analysis was used to identify representative indicator species for each of the wetland types that were included in the study. This test used both abundance and frequency of taxa across designated groups to generate indicator values (IV) from 0 (no indicator value) to 100 (perfect indicator) for every taxon, and Monte Carlo analysis was used to test for significance. Cluster, nMDS and ANOSIM analyses were conducted using PRIMER 7 (Clarke and Gorley 2015), Indicator Analyses were conducted in PC-ORD 5 (MJM Software Design, Glenden Beach, OR, U.S.A.), and ANOVA analyses were carried out using SPSS 21.0 (IBM Corp., Armonk, NY, USA).

\section{Results}

\section{Snail Abundance and Diversity of Restored Wetlands Versus Natural Intertidal Wetlands}

We collected 4148 snails belonging to 16 families, 18 genera and 19 species (Table. 1). Twelve species and 2009 individuals were collected from 19 restored wetland sites, and 10 species and 2139 individuals were collected from 14 non-restored intertidal wetland sites. Restored wetlands averaged 2.01 taxa per site $\left(\mathrm{m}^{2}\right)$, with a range of 0-6 taxa; non-restored wetlands averaged 1.43 taxa per site $\left(\mathrm{m}^{2}\right)$, with a range of 0-6 taxa. Abundance, species richness, Margalef richness, Shannon-wiener diversity and Simpson diversity indexes were not significantly different between restored wetlands and natural intertidal wetlands (ANOVA, $p>0.05$; Fig. 1a). 
Table 1 Average snail abundance (ind $/ \mathrm{m}^{2}$ ) of restored wetlands and natural intertidal wetlands of the Yellow River Delta in Northern China

\begin{tabular}{llll}
\hline Family & Species & Restored wetlands & Natural intertidal wetlands \\
\hline Hydrobiidae & Oncomelania sp. & 0 & $48.70(31.73)$ \\
Bithyniidae & Bithynia longicornis (Benson) & $0.34(0.16)$ & $0.69(0.28)$ \\
Stenothyridae & Stenothyra glabra (A. Adams) & $1.94(0.69)$ & $3.95(1.11)$ \\
Assimineidae & Assiminea violacea Heude & 0 & $0.51(0.39)$ \\
Lymnaeidae & Radix swinhoei (H.Adams) & $15.92(4.11)$ & $0.03(0.03)$ \\
Planorbidae & Hippeutis cantori (Benson) & $11.99(3.10)$ & 0 \\
& Gyraulus convexiusculus (Hütton) & $0.32(0.13)$ & 0 \\
Valvatidae & Valvata piscinalis (Müller) & $0.04(0.04)$ & 0 \\
Succineidae & Succinea pfeifferi Rossmaeller & $5.56(2.65)$ & 0 \\
& Succinea evoluta Martens & $0.79(0.75)$ & 0 \\
Cochlieopidae & Cochlicopa lubrica (Müller) & 0 & $0.23(0.13)$ \\
Pupillidae & Pupilla sp. & $0.55(0.33)$ & 0 \\
& Gastrocopta armigerella (Reinhardt) & $0.13(0.11)$ & 0 \\
Ariophantidae & Kaliella sp. & $0.15(0.07)$ & 0 \\
Batillariidae & Batillaria cumingii Crosse & 0 & $0.03(0.03)$ \\
Nassariidae & Nassarius festivus (Powys) & 0 & $0.15(0.11)$ \\
Cylichnidae & Decorifera matusimana (Nomura) & 0 & $0.03(0.03)$ \\
Pyramidellidae & Monotigma eximia (Lischke) & 0 & $0.26(0.16)$ \\
Siliquariidae & Siliquaria sp. & $0.04(0.03)$ & 0 \\
& Abundance & $37.76(6.32)$ & $54.57(32.31)$ \\
& Taxa richness & $2.01(0.21)$ & $1.43(0.19)$ \\
\hline & & &
\end{tabular}

Data are shown as the average values with standards errors

\section{Snail Abundance and Diversity of Tidal Creeks Versus Non-creek Intertidal Wetlands}

We collected 10 species and 2043 individuals of snails in seven non-creek intertidal wetlands and collected four species and 96 individuals in seven tidal creeks (Table 2). Non-creek intertidal wetlands averaged 1.62 taxa per site $\left(\mathrm{m}^{2}\right)$, with a range of 0-6 taxa; tidal creeks averaged 1.21 taxa per site $\left(\mathrm{m}^{2}\right)$, with a range of 0-3 taxa. Abundance, species richness, Margalef richness, Shannon-wiener diversity and Simpson

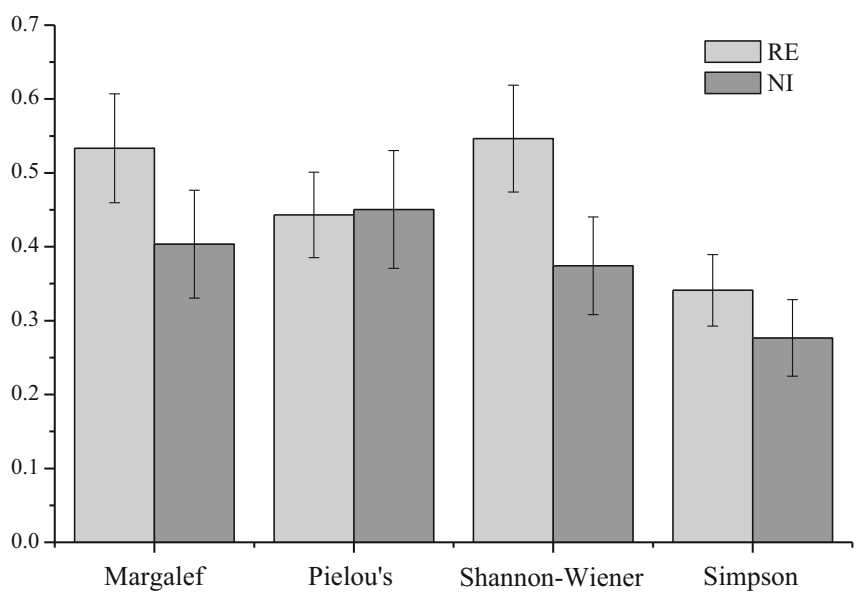

diversity indexes were not significantly different between creek and non-creek habitats (ANOVA, $p>0.05$; Fig. 1b).

\section{Snail Community Assemblages and Indicator Species for Different Wetland Types}

Freshwater release wetlands primarily had freshwater snail species, and natural intertidal wetlands had mainly marine or saltadapted snail species. The dominant species in restored wetlands were Radix swinhoei (H.Adams), Hippeutis cantori (Benson)

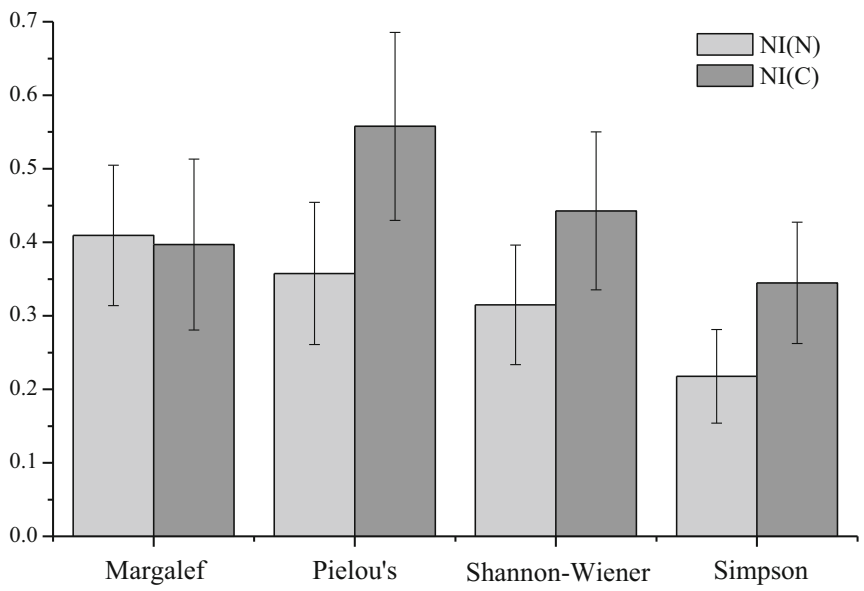

Fig. 1 Four diversity indices of snails in restored wetlands (RE) versus natural intertidal wetlands (NI), and tidal creeks (NI(C)) versus non-creek intertidal wetlands $(\mathrm{NI}(\mathrm{N}))$ 
Table 2 Average snail abundance (ind $/ \mathrm{m}^{2}$ ) of tidal creeks and noncreek intertidal wetlands of natural intertidal wetlands of the Yellow River Delta in Northern China

\begin{tabular}{llll}
\hline Family & Species & non-creek intertidal wetlands & tidal creeks \\
\hline Hydrobiidae & Oncomelania sp. & $89.14(58.07)$ & $2.03(0.90)$ \\
Bithyniidae & Bithynia longicornis & $0.43(0.43)$ & $0.99(0.35)$ \\
Stenothyridae & Stenothyra glabra & $6.33(1.85)$ & $1.21(0.39)$ \\
Assimineidae & Assiminea violacea & $0.05(0.05)$ & $1.04(0.82)$ \\
Lymnaeidae & Radix swinhoei & $0.05(0.05)$ & 0 \\
Cochlieopidae & Cochlicopa lubrica & $0.43(0.23)$ & 0 \\
Batillariidae & Batillaria cumingii & $0.05(0.05)$ & 0 \\
Nassariidae & Nassarius festivus & $0.29(0.19)$ & 0 \\
Cylichnidae & Decorifera matusimana & $0.05(0.05)$ & 0 \\
Pyramidellidae & Monotigma eximia & $0.48(0.29)$ & 0 \\
& Abundance & $97.29(58.95)$ & $5.27(1.45)$ \\
& Taxa richness & $1.62(0.32)$ & $1.21(0.17)$ \\
\hline
\end{tabular}

Data are shown as the average values with standards errors and Succinea pfeifferi Rossmaeller. The dominant species in the natural intertidal wetlands was Oncomelania sp.. Three species, Bithynia longicornis (Benson), Stenothyra glabra (A. Adams) and Radix swinhoei were found both in restored wetlands and natural intertidal wetlands.

Cluster analyses and nMDS ordinations using the snail abundance data identified two major groups of wetlands, which were validated by a SIMPROF test $(p<0.005$; Fig. 2). One group was composed of the restored wetland sites located on both sides of Yellow River channel. The second group included the non-restored sites, and consisted of the salt-adapted species from both tidal creeks and non-creek intertidal wetlands (Table. 3 ). The seven natural non-creek intertidal wetlands and the seven natural tidal creeks clustered into a single group in the nMDS plot (Fig. 2). Two-way ANOSIM indicated that snail assemblages in the sampled wetlands were impacted by freshwater connectivity (ANOSIM $p=0.001$ ) but were not significantly impacted by natural tidal connectivity between creek and non-creek habitats (ANOSIM $p=0.158$ ) (Table. 3).

The species in tidal creeks were all found in non-creek intertidal wetlands, therefore we pooled creeks and noncreek intertidal wetlands together for indicator analyses (Table 4; see vectors in Fig. 2). Three freshwater pulmonate species, Radix swinhoei (Lymnaeidae) (IV =99.7), Hippeutis cantori (Planorbidae) (IV =94.7) and Succinea pfeifferi (Succineidae) $(\mathrm{IV}=42.1)$ were indicator species for restored wetlands. Three species, Oncomelania sp. (Hydrobiidae) (IV=97.6), Stenothyra glabra (Stenothyridae) $(\mathrm{IV}=56.9)$ and Nassarius festivus (Powys) (Nassariidae) (IV =42.9) were indicators for natural intertidal wetlands. When we pooled creeks and noncreek tidal wetlands together, indicator analyses identified no representative indicator species.

\section{Discussion}

We found that artificial freshwater connectivity transformed the intertidal snail assemblages into freshwater snail assemblages in the ecological restoration area. Although species abundance and species richness were similar between restored wetlands and natural intertidal wetlands, the composition and structure of snails were strongly influenced by freshwater connectivity. Simultaneously, we demonstrated that natural hydrological connectivity with the ocean needs to be maintained for invertebrate restoration in intertidal wetlands.

The construction of a levee around the restored area in 2002 retained freshwater connectivity from the Yellow River runoff, but oceanic tides were blocked. In particular, wetland hydrology has been altered using levees, which restrict tidal amplitude and fragment habitats (Boys et al. 2012). This resulted in many changes in the vegetation cover, sediment and water characteristics (Salinity, pH, TOC and velocity of flow; see Yang et al. 2017a). Salinity is considered an important environmental factor that regulates aquatic community structure in inland lakes and wetlands (Verschuren et al. 2000; Waterkeyn et al. 2008) and numerous studies have demonstrated that invertebrate abundance and taxa diversity decline under highly saline conditions (Wu et al. 2019; Yang et al. 2019). Decreases in salinity caused by freshwater introductions and reduced incursions of natural tides because of the construction of levees were major factors affecting snail assemblages of intertidal wetlands. The decrease in salinity resulted in a suitable habitat for some macrophytes (mainly Phragmites australis) (Liu et al. 2018a, b), which in turn likely created a suitable habitat for the survival of some freshwater snails that could use those plants as shelter and as substrate to feed on biofilms. 


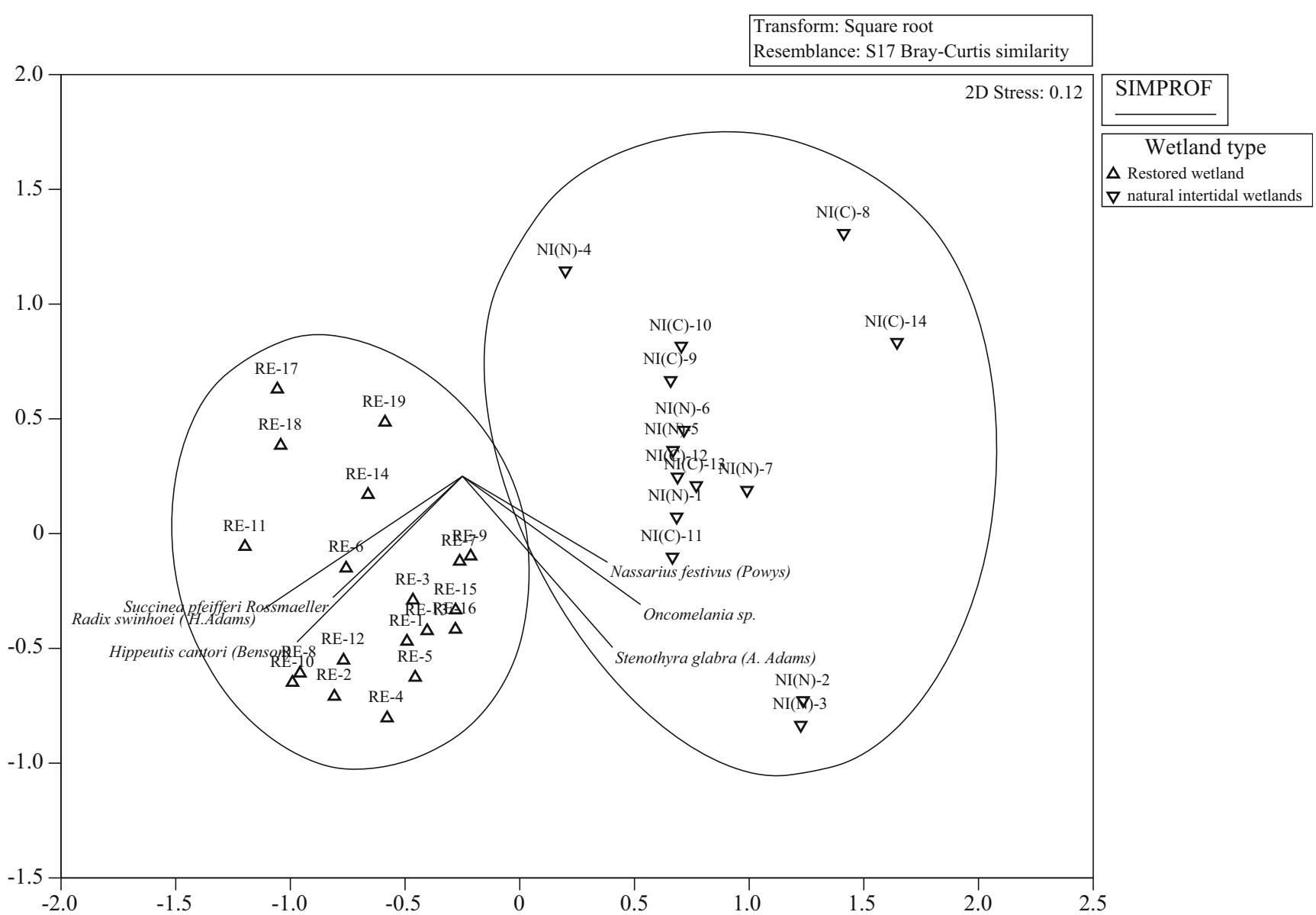

Fig. 2 NMDS ordination of snail abundance using Bray-Curtis similarity in different types of wetlands. Bray-Curtis similarity is used for resemblance distance measure, and the data are transformed by the square root

Tidal creeks are often considered to be passageways and feeding grounds to numerous species of fish, shellfish and crustacean (Mallin 2004). Recent study has found that altered hydrologic connectivity possibly degraded fish and crustacean passage and reduced aquatic assemblages in tidal creeks (Boys et al. 2012). On a biogeographic scale, the distributions of snails are affected by each species' dispersal capacity (Brown and Lydeard 2010). Tidal creeks are expected to accelerate the dispersion of snails through enhancing water flows and providing migration corridors. Most salt water come from the flow of oceanic tides, with a small part coming from freshwater flushing. Freshwater snails were absent from tidal creeks, probably due to the high salinity environments. Overall, the snail assemblages of tidal creeks consisted of marine species which dispersed to and from non-creek intertidal wetlands, and were adapted for dramatic changes in salinity, dissolved oxygen, and temperature.

The indicator species of natural intertidal wetlands were marine species and salt-adapted species, suggesting that the natural intertidal wetlands are ecotones between ocean and terrestrial ecosystems. While past work has focused on using insects for wetland bioassessment, recent work exploring invertebrates support the use of snails as indicator species (Wu et al. 2017, 2019; Guan et al. 2017, 2018). Our findings
Table 3 ANOSIM of snail abundance of restored wetlands versus natural intertidal wetlands, and tidal creeks versus non-creek intertidal wetlands using the Bray-Curtis distance measure

\begin{tabular}{lll}
\hline Factors & Dissimilarity $(p)$ & \\
\hline Restored wetlands versus Natural intertidal wetlands & $0.879(0.001)$ & \\
& Non-creek intertidal wetlands & Tidal creeks \\
Restored wetlands & $0.935(0.001)$ & $0.922(0.001)$ \\
Non-creek intertidal wetlands & & $0.085(0.158)$
\end{tabular}


Table 4 Indicator species analyses for restored wetlands and natural intertidal wetlands

\begin{tabular}{llll}
\hline Wetland type & Indicator species & Indicator value (IV) & $P$ \\
\hline Restored wetlands & Hippeutis cantori & 94.7 & 0.0002 \\
& Radix swinhoei & 99.7 & 0.0002 \\
& Succinea pfeifferi & 42.1 & 0.0384 \\
Natural intertidal wetlands & Stenothyra glabra & 56.9 & 0.0346 \\
& Oncomelania sp. & 97.6 & 0.0004 \\
& Nassarius festivus & 42.9 & 0.0158 \\
\hline
\end{tabular}

The table only lists species that had significant support as indicator species highlight the diversity in the taxonomy, ecology, and physiology of snails found in various kinds of wetlands (coupled with the ease of collection), suggesting that these species would be an attractive model to use for classifying freshwater connectivity of intertidal wetlands in Northern China (Wu et al. 2017). The indicator species of restored wetlands were all freshwater snail species; the indicator species for natural intertidal wetlands were all saltmarsh species. Elsewhere in China, Lymnaeidae species have been identified as indicator species of wetlands (Wu et al. 2017, 2019; Guan et al. 2017, 2018) and Hippeutis cantori and Succinea sp. were identified as indicators for freshwater perennial inundated wetlands, in a combined study of freshwater and saline-alkali wetlands of Northeast China (Wu et al. 2019).

Restoration efforts for wetlands centered on the water, biota and soil, with hydrology restoration or re-establishment being a fundamental objective of restoration projects (Zhao et al. 2016). Introducing freshwater for wetland restoration is a globally recognized way to maintain wetland biodiversity, and to restore or enhance ecosystem services (Yang et al. 2017a). However, restoration of intertidal wetlands by freshwater release changes intertidal snail species compositions into freshwater snail assemblages. Similarly, many species of native shorebirds forage almost exclusively on intertidal habitats (Smart and Gill 2003) rather than freshwater habitats. When restoring intertidal wetlands to recover the original invertebrate foods for shorebirds, it is prerequisite to retain tidal flows and to connect hydrology of tidal creeks with the greater salt marsh expanse to achieve improved invertebrate community and drive other natural improvements in ecosystem function. Restoration goals and methods for successful intertidal wetland restoration efforts will require careful consideration, including accounting for unintended consequences.

Acknowledgments We thank Darold P Batzer in University of Georgia, USA for editing of the English version and some useful suggestions. This study was supported by the National Key R\&D Program of China (2017YFC0505901), the National Natural Science Foundation of China $(41801084,41871099)$, China Postdoctoral Science Foundation (194419), and Jilin Scientific and Technological Development Program (20180101080JC).

\section{References}

Aarts BGW, Van den Brink FWB, Nienhuis PH (2004) Habitat loss as the main cause of the slow recovery of fish faunas of regulated large rivers in Europe: the transversal floodplain gradient. River Research and Applications 20:3-23

Amoros C, Bornette G (2002) Connectivity and biocomplexity in waterbodies of riverine floodplains. Freshwater Biology 47:761-776

Batzer DP, Shurtleff AS, Rader RB (2001) Sampling invertebrates in wetlands. In: Rader RB, Batzer DP, Wissinger SA (eds) Bioassessment and Management of North American Freshwater Wetlands. John Wiley and Sons, New York, pp 339-354

Boys CA, Kroon FJ, Glasby TM, Wilkinson K (2012) Improved fish and crustacean passage in tidal creeks following floodgate remediation. Journal of Applied Ecology 49:223-233

Brown KM, Lydeard C (2010) Chapter 10-Mollusca: Gastropoda. In: Thorp JH, Covich AP (eds) Ecology \& classification of north American freshwater invertebrates, Third edn. Academic press, New York, pp 277-306

Clarke KR, Gorley RN (2015) PRIMER v7 user manual/tutorial. In: PRIMER-E. Plymouth

Cui BS, Yang QC, Yang ZF, Zhang KJ (2009) Evaluating the ecological performance of wetland restoration in the Yellow River Delta, China. Ecological Engineering 35:1090-1103

Dame R, Alber M, Allen D, Mallin M, Montague C, Lewitus A, Chalmers A, Gardner R, Gilman C, Kjerfve B, Pinckney J, Smith N (2000) Estuaries of the South Atlantic coast of North America: their geographical signatures. Estuaries 23:793-819

de Paggi SBJ, Paggi JC (2008) Hydrological connectivity as a shaping force in the zooplankton Community of two Lakes in the Paraná River floodplain. International Review of Hydrobiology 93:659-678

Desmond JS, Zedler JB, Williams GD (2000) Fish use of tidal creek habitats in two southern California salt marshes. Ecological Engineering 14:233-252

Fullerton AH, Burnett KM, Steel EA, Flitcroft RL, Pess GR, Feist BE, Torgersen CE, Miller DJ, Sanderson B (2010) Hydrological connectivity for riverine fish: measurement challenges and research opportunities. Freshwater Biology 55:2215-2237

Guan Q, Wu H, Lu K, Lu X, Batzer DP (2017) Longitudinal and lateral variation in snail assemblages along a floodplain continuum. Hydrobiologia 792:345-356

Guan Q, Liu J, Batzer DP, Wu H (2018) Snails (Mollusca: Gastropoda) as potential surrogates of overall aquatic invertebrate assemblage in wetlands of northeastern China. Ecological Indicators 90:193-200

Hosen JD, Armstrong AW, Palmer MA (2018) Dissolved organic matter variations in coastal plain wetland watersheds: the integrated role of hydrological connectivity, land use, and seasonality. Hydrological Processes 32:1664-1681 
Jin BS, Fu CZ, Zhong JS, Li B, Chen JK, Wu JH (2007) Fish utilization of a salt marsh intertidal creek in the Yangtze River estuary, China. Estuarine, Coastal and Shelf Science 73:844-852

Lasne E, Lek S, Lafaille P (2007) Patterns in fish assemblage in the Loire floodplain: the role of hydrological connectivity and implications for conservation. Biological Conservation 139:258-268

Leigh C, Sheldon F (2009) Hydrological connectivity drives patterns of macroinvertebrate biodiversity in floodplain rivers of the Australian wet/dry tropics. Freshwater Biology 54:549-571

Leng Y, Zhang H, Wang Z (2017) Atlas of common benthic animals in the Yellow Sea and Bohai Sea. China Ocean Press, Beijing

Liu YY, Zhang WZ, Wang YX (1979) Economic Fauna Sinica of China: freshwater Mollusca. Science Press, Beijing

Liu Y, Ding Z, Bachofen C, Lou YJ, Jiang M, Tang XG, Lu XG, Buchmann N (2018a) The effect of saline-alkaline and water stresses on water use efficiency and standing biomass of Phragmites australis and Bolboschoenus planiculmis. Science of the Total Environment 644:207-216

Liu S, Hou X, Yang M, Cheng F, Coxixo A, Wu X, Zhang Y (2018b) Factors driving the relationships between vegetation and soil properties in the Yellow River Delta, China. CATENA 165:279-285

Ma Y, Hu A, Yu C, Yan Q, Yan X, Wang Y, Xiong H (2015) Response of microbial communities to bioturbation by artificially introducing macrobenthos to mudflat sediments for in situ bioremediation in a typical semi-enclosed bay, Southeast China. Marine Pollution Bulletin 94:114-122

Mallin MA (2004) The importance of tidal creek ecosystems. Journal of Experimental Marine Biology and Ecology 298:145-149

Meyer MD, Davis CA, Bidwell JR (2013) Assessment of two methods for sampling invertebrates in shallow vegetated wetlands. Wetlands 33:1063-1073

Ning J, Du F, Wang X, Wang L, Li Y (2019) Trophic connectivity between intertidal and offshore food webs in Mirs Bay, China. Oceanologia 61:208-217

Paillex A, Dolédec S, Castella E, Mérigoux S (2009) Large river floodplain restoration: predicting species richness and trait responses to the restoration of hydrological connectivity. Journal of Applied Ecology 46:250-258

Pennak RW (1989) Fresh-water invertebrates of the United States, Protozoa to Mollusca. Wiley, New York

Qi ZY, Ma XT, Liu YY (1985) Atlas of animal Chinese: Mollusca. Science Press, Beijing

Reckendorfer W, Baranyi C, Funk A, Schiemer F (2006) Floodplain restoration by reinforcing hydrological connectivity: expected effects on aquatic mollusc communities. Journal of Applied Ecology 43:474-484

Reese EG, Batzer DP (2007) Do invertebrate communities in floodplains change predictably along a river's length? Freshwater Biology 52: 226-239

Reid MA, Delong MD, Thoms MC (2012) The influence of hydrological connectivity on food web structure in floodplain lakes. River Research Applications 28:827-844

Sanderson EW, Ustin SL, Foin TC (2000) The influence of tidal channels on the distribution of salt marsh plant species in Petaluma marsh, CA, USA. Plant Ecology 146:29-41

Smart J, Gill JA (2003) Non-intertidal habitat use by shorebirds: a reflection of inadequate intertidal resources? Biological Conservation 111: 359-369

Strong EE, Gargominy O, Ponder WF, Bouchet P (2008) Global diversity of gastropods (Gastropoda; Mollusca) in freshwater. Hydrobiologia 595:149-166
Thayer GW, Kentula ME (2005) Coastal restoration: where have we been, where are we now, and where should we be going? Journal of Coastal Research 40:1-5

Thom RM, Breithaupt SA, Diefenderfer HL, Borde AB, Roegner GC, Johnson GE, Woodruff DL (2018) Storm-driven particulate organic matter flux connects a tidal tributary floodplain wetland, mainstem river, and estuary. Ecological Applications 28:1420-1434

Valdemoro HI, Sánchez-Arcilla A, Jiménez A (2007) Coastal dynamics and wetlands stability. The Ebro delta case. Hydrobiologia 577:17-29

van der Heide T, Tielens E, van der Zee EM, Weerman EJ, Holthuijsen S, Eriksson BK, Piersma T, van de Koppel J, Olff H (2014) Predation and habitat modification synergistically interact to control bivalve recruitment on intertidal mudflats. Biological Conservation 172:163-169

Verschuren D, Tibby J, Sabbe K, Roberts N (2000) Effects of depth, salinity, and substrate on the invertebrate community of a fluctuating tropical lake. Ecology 81:164-182

Wang M, Song X (2017) Biodiversity atlas of marine protected areas in the Shandong Sea area of the Bohai Sea (volume 3): common benthic organisms. China Ocean Press, Beijing

Wang JQ, Tang L, Zhang XD, Wang CH, Gao Y, Jiang LF, Chen JK, Bo L (2009) Fine-scale environmental heterogeneities of tidal creeks affect distribution of crab burrows in a Chinese salt marsh. Ecological Engineering 35:1685-1692

Waterkeyn A, Grillas P, Vanschoenwinkel B, Brendonck L (2008) Invertebrate community patterns in Mediterranean temporary wetlands along hydroperiod and salinity gradients. Freshwater Biology 53:1808-1822

Wu HT, Guan Q, Lu XG, Batzer DP (2017) Snail (Mollusca: Gastropoda) assemblages as indicators of ecological condition in freshwater wetlands of northeastern China. Ecological Indicators 75:203-209

Wu W, Yang Z, Tian B, Huang Y, Zhou Y, Zhang T (2018) Impacts of coastal reclamation on wetlands: loss, resilience, and sustainable management. Estuarine, Coastal and Shelf Science 210:153-161

Wu HT, Guan Q, Ma HY, Xue ZS, Yang MY, Batzer DP (2019) Effects of saline conditions and hydrologic permanence on snail assemblages in wetlands of northeastern China. Ecological Indicators 96:620-627

Yang W (2011) A multi-objective optimization approach to allocate environmental flows to the artificially restored wetlands of China's Yellow River Delta. Ecological Modelling 222:261-267

Yang W, Li X, Sun T, Yang Z, Li M (2017a) Habitat heterogeneity affects the efficacy of ecological restoration by freshwater releases in a recovering freshwater coastal wetland in China's Yellow River Delta. Ecological Engineering 104 Part A:1-12

Yang W, Li X, Sun T, Pei J, Li M (2017b) Macrobenthos functional groups as indicators of ecological restoration in the northern part of China's Yellow River Delta wetlands. Ecological Indicators 82: 381-391

Yang MY, Lu K, Batzer DP, Wu HT (2019) Freshwater release into estuarine wetlands changes the structure of benthic invertebrate assemblages: a case study from the Yellow River Delta. Science of the Total Environment 687:752-758

Zhao Q, Bai J, Huang L, Gu B, Lu Q, Gao Z (2016) A review of methodologies and success indicators for coastal wetland restoration. Ecological Indicators 60:442-452

Publisher's Note Springer Nature remains neutral with regard to jurisdictional claims in published maps and institutional affiliations. 